\section{Nitrogen, Calcium, and Magnesium Inconsistently Affect Tree Growth, Fruit Yield, and Juice Quality of Huanglongbing-affected Orange Trees}

Eduardo Esteves

Soil and Water Sciences Department, University of Florida, Citrus Research and Education Center, Lake Alfred, FL 33850

Gabriel Maltais-Landry

Soil and Water Sciences Department, University of Florida, Gainesville, FL 32611

Flavia Zambon

Soil and Water Sciences Department, University of Florida, Citrus Research and Education Center, Lake Alfred, FL 33850

\section{Rhuanito Soranz Ferrarezi \\ Horticultural Sciences Department, University of Florida, Indian River Research and Education Center, Fort Pierce FL 34945; and Department of Horticulture, University of Georgia, Athens, GA 30602 \\ Davie M. Kadyampakeni \\ Soil and Water Sciences Department, University of Florida, Citrus Research and Education Center, Lake Alfred, FL 33850}

Additional index words. citrus greening, citrus sinensis, macronutrients, plant nutrition

Abstract. The bacterial disease Huanglongbing (HLB) has drastically reduced citrus production in Florida. Nutrients play an important role in plant defense mechanisms and new approaches to manage the disease with balanced nutrition are emerging. Nutrients like nitrogen $(\mathrm{N})$, calcium $(\mathrm{Ca})$, and magnesium $(\mathrm{Mg})$ could extend the productive life of affected trees, although interactions among these nutrients in HLB-affected citrus trees are still unclear. A 2-year study was established in Florida to determine the response of HLBaffected trees to applications of $\mathrm{N}, \mathrm{Ca}$, and $\mathrm{Mg}$. The study was conducted with 'Valencia' trees (Citrus sinensis L. Osbeck) on Swingle citrumelo (Citrus paradisi Macf. $\times$ Poncirus trifoliata L. Raf.) rootstock on a Candler sand. Applications of $\mathrm{N}$ at 168, 224 (recommended rate), and $280 \mathrm{~kg} \cdot \mathrm{ha}^{-1} \mathrm{~N}$ were used as the main plots. Split-plots consisted of a grower standard treatment receiving only basal Ca $\left(51 \mathrm{~kg}^{-\mathrm{ha}^{-1}}\right)$ and $\mathrm{Mg}\left(56 \mathrm{~kg} \cdot \mathrm{ha}^{-1}\right)$; supplemental Ca (total Ca inputs: $96 \mathrm{~kg} \cdot \mathrm{ha}^{-1}$ ) only; supplemental $\mathrm{Mg}$ (total $\mathrm{Mg}$ inputs: $101 \mathrm{~kg} \cdot \mathrm{ha}^{-1}$ ) only; and supplemental Ca (total $\mathrm{Ca}$ inputs: $73.5 \mathrm{~kg} \cdot \mathrm{ha}^{-1}$ ) and $\mathrm{Mg}$ (total $\mathrm{Mg}$ inputs: 78.5 $\mathrm{kg} \cdot \mathrm{ha}^{-1}$ ). The following variables were measured: tree size, fruit yield, and juice quality. Although some differences in tree growth among treatments were statistically significant (e.g., greater canopy volume with $\mathrm{Mg}$ fertilization at $168 \mathrm{~kg} \cdot \mathrm{ha}^{-1} \mathrm{~N}$ ), there was no clear and consistent effect of plant nutrition on these variables. Fruit yield was higher with $\mathrm{Ca}$ and Mg relative to the grower standard at the lowest $\mathrm{N}$ rate in 2020, and there were no other statistically significant differences among treatments. Juice acidity was significantly higher with Mg fertilization relative to other treatments in 2019. As N rates had no significant effect in this study, unlike secondary macronutrients, $N$ rates could potentially be reduced to $168 \mathrm{~kg} \mathrm{~N} \cdot \mathrm{ha}^{-1}$ in $\mathrm{HLB}$-affected citrus without affecting vegetative growth, fruit yield, and juice quality. However, this will require optimizing the supply of secondary macronutrients and all other nutrients to develop a balanced nutritional program. Ultimately, the effects of N, Ca, and Mg obtained in this 2-year study should be confirmed with longerterm studies conducted at multiple sites.

Citrus production in Florida has been decreasing over the past 15 years due to several factors (Florida Department of Agriculture and Consumer Services, 2020), with HLB being a major driver (Alvarez et al., 2016; Kadyampakeni et al., 2015). This disease has severe effects on citrus growth and production, including stunted vegetative and diseases, as well-fertilized plants are less susceptible than nutrient-deficient ones (García-Mina, 2012; Spann and Schumann, 2010). Recent evidence suggests that HLB symptoms in citrus can be reduced with a balanced nutritional program, including improved irrigation, fertigation, and nutrient management (Atta, 2019; Atta et al., 2020; Handique et al., 2012; Kadyampakeni et al., 2016; Morgan et al., 2016; Phuyal et al., 2020a, 2020b; Rouse et al., 2012; Uthman et al., 2020b, 2020a; Zambon et al., 2019). Thus, until commercially available resistant citrus varieties are developed, limiting the effects of HLB by focusing on nutrient management can help keep commercial growers in production (Alvarez et al., 2016; Spann and Schumann, 2010).

Each nutrient has specific roles in plant growth, with some elements directly affecting defense mechanisms. $\mathrm{N}$ has a strong influence on tissue growth, fruit production, and fruit quality, more so than any other element (Obreza and Morgan, 2008; Zekri, 2016). Ca is essential for plant cell walls and structural integrity, hence lower $\mathrm{Ca}$ concentrations in young flush leaves or shoots make citrus trees more susceptible to the HLB vector, the Asian citrus psyllid (Diaphorina citri; Sétamou et al., 2016). Mg is involved in starch catabolism and sucrose formation (Zhou et al., 2018). Classic $\mathrm{Mg}$ deficiency symptoms in citrus resemble the blotchy mottle leaves in HLB-affected plants, as accumulation of callose and p-protein in the phloem sieve pores restricts phloem movement and promotes accumulation of carbohydrates in leaves (Hawkesford et al., 2012; Huber and Jones, 2013).

The effects of $\mathrm{N}, \mathrm{Ca}$, and $\mathrm{Mg}$ fertilizer applications have been evaluated with vegetative growth variables for decades, such as tree canopy measurements (Calvert, 1970; Hart and Gaultney, 1991; Obreza and Rouse, 1993; Morgan et al., 2007; Zambon et al., 2019) and trunk cross-sectional area (TCSA) (Calvert, 1970; Obreza and Rouse, 1993; Zambon et al., 2019), as there is generally a direct relationship between canopy size and productivity (Vashisth et al., 2020). Morgan et al. (2006) found a linear relationship between total tree $\mathrm{N}$ uptake, TCSA, and canopy volume, in 3- to 15-year-old 'Hamlin' orange trees on Swingle rootstock, whereas Morgan et al. (2009) found no significant effect of different $\mathrm{N}$ rates on the canopy volume of 8- to 10-year-old 'Ambersweet' oranges on Swingle rootstock. Calvert (1970) found no significant effect of dolomitic lime application on tree canopy volume and trunk size, although $\mathrm{Mg}$ uptake by citrus trees might have been limited by the low solubility of dolomitic lime. More recently, using HLB-affected trees, Atta (2019) found that canopy volume was not significantly affected by application of $\mathrm{Ca}, \mathrm{Mg}$, and a combination of $\mathrm{Ca}$ and $\mathrm{Mg}$ on 10- to 13-year-old 'Hamlin' trees budded on two rootstocks (Swingle and Cleopatra), although treatments receiving $\mathrm{Ca}$ and/or $\mathrm{Mg}$ had significantly greater leaf area indices than the control. Overall, the effects of N, Ca, and $\mathrm{Mg}$ on vegetative growth are not consistent, which could be driven by many factors 
that influence the effect of nutrients on vegetative growth, including soil characteristics, rootstock, scion, fertilizer forms, and fertilizer rates (Atta, 2019; Calvert, 1970; Koo, 1971; Quaggio et al., 2014; Uthman, 2019). As several studies were conducted before HLB became widespread in the state, it is critical to evaluate the role that $\mathrm{N}, \mathrm{Ca}$, and $\mathrm{Mg}$ could have on vegetative tree growth variables.

As fruit yield is one of the most important response variables when testing fertilizers and a major outcome that matters to citrus growers, the effects of fertilization on citrus yields have been studied extensively (Calvert, 1970; Koo, 1971; Obreza and Rouse, 1993; Quaggio et al., 2019; Schumann et al., 2003; Vang-Petersen, 1980; Weir, 1969). In a fertigated system, Quaggio et al. (2019) obtained significantly higher yields $\left(\approx 53 \mathrm{t} \cdot \mathrm{ha}^{-1}\right)$ on 4-year-old 'Natal' sweet orange trees on Rangpur lime rootstock with a combination of $120 \mathrm{~kg} \cdot \mathrm{ha}^{-1}$ $\mathrm{N}$ and $80 \mathrm{~kg} \cdot \mathrm{ha}^{-1} \mathrm{~K}_{2} \mathrm{O}$ (50\% rate) compared with the $50 \mathrm{t} \mathrm{ha}^{-1}$ yield obtained with a treatment that doubled those respective rates (100\% rate), indicating that higher $\mathrm{N}$ rates do not necessarily translate into higher yields. In 'Hamlin' orange grafted on Swingle rootstock, Schumann et al. (2003) obtained a quadratic response for yield when using dry granular fertilization, and the highest yield $\left(\approx 20 \mathrm{t} \cdot \mathrm{ha}^{-1}\right)$ was obtained with an $\mathrm{N}$ rate of $\approx 160$ $\mathrm{kg} \cdot \mathrm{ha}^{-1} \mathrm{~N}$. This rate is lower than the current recommendation of $224 \mathrm{~kg} \cdot \mathrm{ha}^{-1} \mathrm{~N}$, but results from Schumann et al. (2003) were obtained with non-HLB-affected trees. As HLB affects citrus growth, root development, and nutrient uptake relative to healthy trees, Shahzad et al. (2020) recommended increasing nutrient inputs slightly relative to recommendations in HLB-affected trees to compensate for poorer nutrient uptake. Hence, it is critical to revisit $\mathrm{N}, \mathrm{Ca}$, and $\mathrm{Mg}$ fertility guidelines in the HLB context to ensure that yield remains acceptable for citrus growers.

HLB may also affect fruit quality by decreasing sweetness (soluble solids content) and increasing acidity, similar to immature fruits (Bassanezi et al., 2009; Dagulo et al., 2010; Dala-Paula et al., 2019). N, Ca, and $\mathrm{Mg}$ may influence the internal quality of the fruit, and juice quality variables have been the focus of several experiments, including those of Koo (1971), Quaggio et al. (1992),

Received for publication 17 May 2021. Accepted for publication 26 July 2021.

Published online 10 September 2021.

Funding was provided by the University of Florida/Institute of Food and Agricultural Sciences (UF/IFAS) Citrus Initiative and U.S. Department of Agriculture Multiagency Coordination Animal and Plant Health Inspection Service Agreement No. AP19PPQSandT00C116. We thank all the members from the Nutrient and Water Management Laboratory of the UF/IFAS Citrus Research and Education Center for technical support.

D.M.K. is the corresponding author. E-mail: dkadyampakeni@ufl.edu.

This is an open access article distributed under the CC BY-NC-ND license (https://creativecommons. org/licenses/by-nc-nd/4.0/). and Calvert (1970). However, there is no consensus regarding the effects of these nutrients on juice quality variables (Koo, 1988; Quaggio et al., 1992).

This study evaluated the effect of different rates and combinations of $\mathrm{N}, \mathrm{Ca}$, and $\mathrm{Mg}$ on canopy volume, TCSA, fruit yield, and juice quality of HLB-affected citrus trees. It was hypothesized that these variables would increase proportionally with the increase in $\mathrm{N}$ rate. Also, it was expected that the addition of supplemental $\mathrm{Ca}$ and $\mathrm{Mg}$ would increase these variables, with the best results observed when combining supplemental $\mathrm{Ca}$ and $\mathrm{Mg}$ instead of using either alone.

\section{Materials and Methods}

Site description and experimental design. The experiment started in January 2018 and was completed in Mar. 2020 at the University of Florida Institute of Food and Agricultural Science (UF/IFAS) Citrus Research and Education Center at Lake Alfred, FL $\left(28.09^{\circ} \mathrm{N}\right.$, $81.75^{\circ} \mathrm{W}$ ), on a Candler sand (hyperthermic, coated, Lamellic Quartzipsamment). It consisted of 6-year-old 'Valencia' orange trees (C. sinensis L. Osbeck) on Swingle citrumelo (C. paradisi Macf. $\times$ P. trifoliata $\mathrm{L}$. Raf.) rootstock, planted in Aug. 2012. Planting density was 1111 trees per hectare with trees spaced at $1.97 \mathrm{~m}$ apart and $4.6 \mathrm{~m}$ between rows, representing $\approx 3$ times a typical grove planting density, which triggers tree competition for resources such as sunlight, water, and nutrients, and results in overlapping rooting zones. From 2012 to 2017, these trees were fertilized with calcium nitrate $(15.5-0-0-19)$ and ammonium nitrate (34-0-0).

All plots were irrigated with $40 \mathrm{~L} \cdot \mathrm{ha}^{-1}$ microsprinkler emitters (Maxjet, Dundee, FL), with one emitter per two trees having a wetting radius of $\approx 1.5 \mathrm{~m}$. Irrigation was applied at 8:00 AM and 1:00 PM daily for $30 \mathrm{~min}$ at each irrigation event according to the UF/IFAS recommended rate, which states that maximum soil water depletion should not exceed $25 \%$ to $33 \%$ of available water from February to June and $50 \%$ to $66 \%$ from July to January (Kadyampakeni et al., 2018). Measurement trees in each plot were tested for Candidatus Liberibacter asiaticus (CLas), using a quantitative real-time polymerase chain reaction (qPCR) (Li et al., 2006). All trees showed visual symptoms of HLB and tested positive for the qPCR test. No trees died during the experiment, and trees were pruned once in Oct. 2017 just before starting the treatments.

A randomized complete block design was used for the experiment. Main plots consisted of $\mathrm{N}$ applications at rates of 168,224 , and $280 \mathrm{~kg} \cdot \mathrm{ha}^{-1}$, applied four times per year (January-February, March-April, June-July, and September-October), where $224 \mathrm{~kg} \cdot \mathrm{ha}^{-1}$ is the UF/IFAS recommended rate. The trees were supplied with fertilizer containing a known amount of nutrients in four equal splits per year given in percentage as $9.75 \%$ $\mathrm{N}, 2 \% \mathrm{P}_{2} \mathrm{O}_{5}, 13 \% \mathrm{~K}_{2} \mathrm{O}, 2.28 \% \mathrm{Ca}, 2.5 \% \mathrm{Mg}$, $11.69 \% \mathrm{~S}, 0.03 \% \mathrm{~B}, 0.27 \% \mathrm{Fe}, 0.55 \% \mathrm{Mn}$, and $0.19 \% \mathrm{Zn}$ to meet the basal rate of 168 $\mathrm{kg} \cdot \mathrm{ha}^{-1} \mathrm{~N}$. The $\mathrm{N}$ source for the granular blend was ammonium nitrate (Diamond Fertilizer, Winter Garden, FL). To meet the additional $\mathrm{N}$ requirements for the higher rates (224 and $\left.280 \mathrm{~kg} \cdot \mathrm{ha}^{-1} \mathrm{~N}\right), \mathrm{N}$ was applied as urea (46-0-0) and the inputs of all other elements were identical to the $168 \mathrm{~kg} \cdot \mathrm{ha}^{-1} \mathrm{~N}$ treatment. Split-plots consisted of secondary macronutrient treatments: $\mathrm{Ca}$ applied as calcium sulfate $(23 \% \mathrm{Ca}$ and $18 \% \mathrm{~S})$ at 45 $\mathrm{kg} \cdot \mathrm{ha}^{-1} ; \mathrm{Mg}$ applied as magnesium sulfate $(10 \% \mathrm{Mg}$ and $14 \% \mathrm{~S})$ at $45 \mathrm{~kg} \cdot \mathrm{ha}^{-1} ; \mathrm{Ca}+$ $\mathrm{Mg}$ applied at $22.5 \mathrm{~kg} \cdot \mathrm{ha}^{-1}$ each; and a grower standard treatment receiving only basal $\mathrm{Ca}$ and $\mathrm{Mg}$ in the blend. Thus, the secondary macronutrient treatments were: 1) $\mathrm{Ca}$ treatment: supplemental Ca (total: $96 \mathrm{~kg} \cdot \mathrm{ha}^{-1}$ Ca) and basal $\mathrm{Mg}$ (56 kg.ha $\left.{ }^{-1} \mathrm{Mg}\right)$; 2) $\mathrm{Ca}+\mathrm{Mg}$ treatment: supplemental $\mathrm{Ca}$ (total: $73.5 \mathrm{~kg} \cdot \mathrm{ha}^{-1} \mathrm{Ca}$ ) and supplemental $\mathrm{Mg}$ (total: $78.5 \mathrm{~kg} \cdot \mathrm{ha}^{-1} \mathrm{Mg}$ ); 3) $\mathrm{Mg}$ treatment: basal $\mathrm{Ca}\left(51 \mathrm{~kg} \cdot \mathrm{ha}^{-1} \mathrm{Ca}\right)$ and supplemental $\mathrm{Mg}$ (total: $101 \mathrm{~kg} \cdot \mathrm{ha}^{-1} \mathrm{Mg}$ ); and 4) Grower standard treatment: basal $\mathrm{Ca}\left(51 \mathrm{~kg} \cdot \mathrm{ha}^{-1} \mathrm{Ca}\right)$ and basal $\mathrm{Mg}\left(56 \mathrm{~kg} \cdot \mathrm{ha}^{-1} \mathrm{Mg}\right)$. These secondary macronutrients were applied three times per year (February, July, and October). The experiment had three blocks, with one plot per treatment in each block and 10 trees per plot; only the eight middle trees were used for yield measurements, six of the eight middle trees were used for canopy volume determinations, and four of the eight middle trees were used for TCSA measurements.

Leaf analysis. Leaf tissue samples were analyzed for macronutrients in Nov. 2017 and Mar. 2020 (Table 1), using dry ash digestion (Hanlon et al., 1997). Three mature leaves were sampled per quadrant of the tree (northeast, southeast, northwest, and southwest) for the six middle trees of each plot and were pooled into one sample of 72 leaves. These leaves were washed with deionized water, dried at $65^{\circ} \mathrm{C}$ for $72 \mathrm{~h}$ immediately after being washed, and passed through a 60-mesh sieve grinder. Tissue analyses were conducted by Waters Agricultural Laboratories Inc. (Camilla, GA) using inductively coupled plasma atomic emission spectrometry analysis for $\mathrm{Ca}$ and $\mathrm{Mg}$ (Munter et al., 1984; Plank, 1992) and dry combustion for N (Anderson and Henderson, 1988). The level of nutrient sufficiency in leaf tissue was determined according to current guidelines used in Florida (Hanlon et al., 1997; Munter et al., 1984; Obreza and Morgan, 2008).

Tree growth measurements. Canopy volume was determined every 6 months in Mar. and Sept. 2018, 2019, and 2020 by measuring the height and the canopy diameter in eastwest and north-south directions, from the six middle trees in each plot. Canopy volume was calculated using the formula for the prolate spheroid shape (Obreza and Rouse, 1993):

$$
\begin{aligned}
\text { Canopy volume }= & \frac{4}{3} * \pi * \frac{\text { tree height }}{2} \\
& *(\text { mean canopy radius })^{2}
\end{aligned}
$$

TCSA was estimated by measuring trunk diameters from the four middle trees in each 
plot, in east-west and north-south directions, and calculated assuming a circular shape:

$$
\text { TCSA }=\pi^{*}(\text { mean trunk radius })^{2}
$$

Yield and juice quality variables. Fruit yield was measured annually by harvesting all the fruits from the eight middle trees of each plot in a single day each year (on 15 Mar. 2018, 15 Apr. 2019, and 18 Mar. 2020), computing yield per plot, and converting to yield per hectare. Juice quality was determined annually by estimating total soluble solids (TSS) and acidity following the procedures described by Wardowski et al. (1995). Approximately 60 oranges per plot were taken for juice quality analysis. TSS/acidity ratio was determined by dividing TSS by titratable acidity.

Data analysis. All analyses were performed in R (version 4.0; R Core Team, 2017), and were considered to be significant at $P<$ 0.05 and marginally significant at $P<0.1$.

Canopy volume, TCSA, and yield were first analyzed using sampling time as the within-subject factor in a repeated-measures model and $\mathrm{N}$ rates and macronutrient applications as between-subject factors. All dates (five for canopy volume and TCSA, three for yield) were included, and the ezANOVA function from the $e z$ package was used to compute repeated-measures analysis of variance (ANOVA). The sphericity condition required for repeated-measures ANOVAs was tested using Mauchly's test, and when this test was significant, $P$ values were corrected using the Greenhouse-Geisser correction for sampling time and its interactions with other factors.

Because time and/or its interaction with $\mathrm{N}$ or macronutrient applications had a significant effect in repeated-measures ANOVAs for canopy volume, TCSA, and yield (Table 2), each spring sampling date was further analyzed individually to explore the effects of $\mathrm{N}$ and macronutrient applications in greater detail. Thus, each March sampling date was analyzed with a split-plot ANOVA (function ANOVA in the car package), using a mixed model (function lme in nlme package). $\mathrm{N}$ rates and macronutrient applications were designated as the between-subject factors and the error of the whole plot consisted of $\mathrm{N}$ rates nested within blocks. When the ANOVA results were significant, a Tukey's honestly significant difference (HSD) test was used to compare the different levels or conditions using the emmeans function (from the emmeans package), and the compact letter display (cld function from the multcomp package) was used to visualize the pattern of the response. Interactions were analyzed by comparing secondary macronutrients within each $\mathrm{N}$ rate, to minimize the number of comparisons performed by the Tukey's HSD test and the associated adjustment of the $P$ values necessary to reduce the type I error. When raw data did not meet the linear model assumptions, variables were individually tested and transformed to meet the linearity, normality, and homoscedasticity assumptions.

Finally, to take into consideration initial conditions that varied among plots and blocks at the beginning of the experiment, percent change in canopy volume and fruit yield was computed as follows:

Percent change $=\frac{2020 \text { value }-2018 \text { value }}{2018 \text { value }}$

This evaluated more accurately whether there was an increase, decrease, or no change in canopy volume or yield during the experiment. Percent change values were subject to the same ANOVA procedure as the one detailed previously for individual spring dates.

\section{Results}

Leaf analysis. In Nov. 2017, all treatments were similar before imposing the treatments (Table 1), and leaf $\mathrm{N}$ was considered to be deficient while $\mathrm{Ca}$ and $\mathrm{Mg}$ were in the optimum range. In 2020, N rates were not significantly different with respect to $\mathrm{N}, \mathrm{Ca}$, and $\mathrm{Mg}$ leaf concentration, but $\mathrm{Ca}$ and $\mathrm{Mg}$ remained in the optimum range while $\mathrm{N}$ was slightly below the optimum range, which is typical because $\mathrm{N}$ is remobilized into citrus fruits in spring. However, the $\mathrm{Ca}$ treatment had significantly greater leaf $\mathrm{Ca}$ concentration relative to other macronutrient application rates $(P=0.039)$ particularly at 168 $\mathrm{kg} \cdot \mathrm{ha}^{-1} \mathrm{~N}$, whereas there was no effect of secondary macronutrients at the other $\mathrm{N}$ rates. Leaf $\mathrm{Mg}$ was highest $(P<0.001)$ with the $\mathrm{Mg}$ or $\mathrm{Mg}+\mathrm{Ca}$ treatments, with stronger effects at 224 and $280 \mathrm{~kg} \cdot \mathrm{ha}^{-1} \mathrm{~N}$.

Canopy volume. Canopy volume was significantly affected by $\mathrm{N}$ rates $(P<0.001)$, secondary macronutrients $(P=0.017)$, and time $(P<0.001)$, with significant interactions among these factors (Table 2). The different $\mathrm{N}$ rates were statistically different in Mar. $2018(P=0.036)$ and Sept. $2019(P=$ $0.044)$ and marginally significant $(P<0.1)$ on the other three measurement dates (Table 3, Supplemental Tables 1 and 2). Canopy volume was statistically different among secondary macronutrient treatments for all time points, except in Mar. $2018(P=0.083)$. The interaction between $\mathrm{N}$ rates and secondary macronutrients was significant at each sampling date $(P<0.01)$.

In Mar. 2018, canopy volume was greater in the $\mathrm{Ca}$ and $\mathrm{Ca}+\mathrm{Mg}$ treatments relative to the grower standard at $280 \mathrm{~kg} \cdot \mathrm{ha}^{-1} \mathrm{~N}$ (Fig. 1A). In Mar. 2019, canopy volume was statistically higher with $\mathrm{Mg}$ fertilization than other treatments at $168 \mathrm{~kg} \cdot \mathrm{ha}^{-1} \mathrm{~N}$, whereas

Table 1. Leaf nitrogen $(\mathrm{N})$, calcium $(\mathrm{Ca})$, and magnesium $(\mathrm{Mg})$ concentrations in Huanglongbing-affected 'Valencia' citrus trees in Oct. 2017 and Mar. 2020 , as affected by $\mathrm{N}$ rates and secondary macronutrients.

\begin{tabular}{|c|c|c|c|c|c|c|c|}
\hline \multirow[b]{2}{*}{ Nitrogen rate } & \multirow[b]{2}{*}{ Macronutrient $^{\mathrm{z}}$} & \multicolumn{2}{|c|}{$\mathrm{N}(\%)^{\mathrm{y}}$} & \multicolumn{2}{|c|}{$\mathrm{Ca}(\%)$} & \multicolumn{2}{|c|}{$\mathrm{Mg}(\%)$} \\
\hline & & 2017 & 2020 & 2017 & 2020 & 2017 & 2020 \\
\hline \multirow[t]{3}{*}{$168 \mathrm{~kg} \cdot \mathrm{ha}^{-1} \mathrm{~N}$} & $\mathrm{Ca}$ & $2.39 \pm 0.07$ & $2.43 \pm 0.06$ & $3.64 \pm 0.12$ & $4.00 \pm 0.00$ & $0.28 \pm 0.02$ & $0.27 \pm 0.03$ \\
\hline & $\mathrm{Ca}+\mathrm{Mg}$ & $2.28 \pm 0.02$ & $2.33 \pm 0.06$ & $3.76 \pm 0.82$ & $3.50 \pm 0.36$ & $0.29 \pm 0.11$ & $0.29 \pm 0.02$ \\
\hline & Grower standard & $2.28 \pm 0.02$ & $2.37 \pm 0.12$ & $3.76 \pm 0.82$ & $3.53 \pm 0.59$ & $0.29 \pm 0.11$ & $0.31 \pm 0.03$ \\
\hline \multirow[t]{2}{*}{$224 \mathrm{~kg} \cdot \mathrm{ha}^{-1} \mathrm{~N}$} & $\mathrm{Ca}$ & $2.23 \pm 0.07$ & $2.40 \pm 0.10$ & $3.15 \pm 0.45$ & $3.57 \pm 0.35$ & $0.29 \pm 0.06$ & $0.26 \pm 0.01$ \\
\hline & $\mathrm{Ca}+\mathrm{Mg}$ & $2.32 \pm 0.01$ & $2.37 \pm 0.12$ & $3.15 \pm 0.43$ & $3.57 \pm 0.31$ & $0.24 \pm 0.09$ & $0.36 \pm 0.03$ \\
\hline \multirow{3}{*}{$280 \mathrm{~kg} \cdot \mathrm{ha}^{-1} \mathrm{~N}$} & $\mathrm{Ca}+\mathrm{Mg}$ & $2.34 \pm 0.12$ & $2.40 \pm 0.17$ & $3.74 \pm 0.06$ & $3.23 \pm 0.32$ & $0.33 \pm 0.04$ & $0.30 \pm 0.06$ \\
\hline & $\mathrm{Mg}$ & $2.42 \pm 0.13$ & $2.33 \pm 0.06$ & $3.65 \pm 0.10$ & $3.20 \pm 0.36$ & $0.26 \pm 0.06$ & $0.34 \pm 0.02$ \\
\hline & Grower standard & $2.26 \pm 0.11$ & $2.33 \pm 0.23$ & $3.23 \pm 0.17$ & $3.43 \pm 0.15$ & $0.28 \pm 0.06$ & $0.26 \pm 0.01$ \\
\hline
\end{tabular}

Factors

\begin{tabular}{|c|c|c|c|c|c|c|}
\hline $\mathrm{N}$ & 0.44 & 0.452 & 0.87 & 0.279 & 0.93 & 0.291 \\
\hline Macronutrients & 0.19 & 0.194 & 0.79 & $0.039 *$ & 0.68 & $<0.001 * * *$ \\
\hline $\mathrm{N} \times$ macronutrients & 0.29 & $0.027 *$ & 0.25 & 0.367 & 0.27 & 0.067 \\
\hline
\end{tabular}

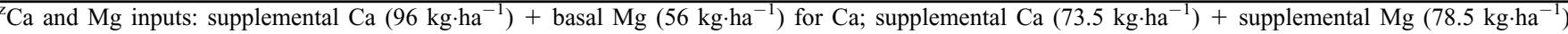
for $\mathrm{Ca}+\mathrm{Mg}$; basal Ca $\left(51 \mathrm{~kg} \cdot \mathrm{ha}^{-1}\right)+$ supplemental Mg $\left(101 \mathrm{~kg} \cdot \mathrm{ha}^{-1}\right)$ for $\mathrm{Mg}$; basal Ca $\left(51 \mathrm{~kg} \cdot \mathrm{ha}^{-1}\right)$ and basal Mg $\left(56 \mathrm{~kg} \cdot \mathrm{ha}{ }^{-1}\right)$ for grower standard. ${ }^{\mathrm{y}}$ Optimum nutrient concentration ranges: $2.5 \%$ to $2.7 \%$ for $\mathrm{N}, 3.0 \%$ to $4.9 \%$ for $\mathrm{Ca}$, and $0.30 \%$ to $0.49 \%$ for $\mathrm{Mg}$.

*, ***Significant at $P<0.05$ or 0.001 , respectively. 
Table 2. Analysis of variance with repeated measures for canopy volume, trunk cross-sectional area (TCSA), and yield of Huanglongbing-affected 'Valencia' citrus trees between 2018 and 2020 .

\begin{tabular}{|c|c|c|c|c|}
\hline Effect $^{\mathrm{z}}$ & $d f^{y}$ & $\mathrm{DDF}^{\mathrm{y}}$ & F-value & $\begin{array}{c}\text { Probability } \\
\text { value }\end{array}$ \\
\hline \multicolumn{5}{|c|}{ Canopy volume } \\
\hline $\mathrm{N}$ & 2 & 204 & 12.6 & $<0.001 * * *$ \\
\hline S & 3 & 204 & 3.5 & $0.017 *$ \\
\hline $\mathrm{T}$ & 4 & 816 & 391.5 & $<0.001^{* * * x}$ \\
\hline $\mathrm{N} \times \mathrm{S}$ & 6 & 204 & 3.5 & $0.003^{* *}$ \\
\hline $\mathrm{N} \times \mathrm{T}$ & 8 & 816 & 4.0 & $0.021^{* \mathrm{x}}$ \\
\hline $\mathrm{S} \times \mathrm{T}$ & 12 & 816 & 1.3 & $0.171^{\mathrm{x}}$ \\
\hline $\mathrm{N} \times \mathrm{S} \times \mathrm{T}$ & 24 & 816 & 1.3 & $<0.001^{* * * \times}$ \\
\hline \multicolumn{5}{|c|}{ TCSA } \\
\hline $\mathrm{N}$ & 2 & 96 & 3.4 & $0.036^{*}$ \\
\hline S & 3 & 96 & 4.0 & $0.01 *$ \\
\hline $\mathrm{T}$ & 4 & 384 & 3.8 & $0.039^{* \mathrm{x}}$ \\
\hline $\mathrm{N} \times \mathrm{S}$ & 6 & 96 & 2.7 & $0.018^{*}$ \\
\hline $\mathrm{N} \times \mathrm{T}$ & 8 & 384 & 1.1 & $0.352^{\mathrm{x}}$ \\
\hline $\mathrm{S} \times \mathrm{T}$ & 12 & 384 & 0.4 & $0.806^{\mathrm{x}}$ \\
\hline $\mathrm{N} \times \mathrm{S} \times \mathrm{T}$ & 24 & 384 & 0.9 & $0.506^{\mathrm{x}}$ \\
\hline \multicolumn{5}{|c|}{ Yield } \\
\hline $\mathrm{N}$ & 2 & 24 & 2.5 & 0.106 \\
\hline S & 3 & 24 & 1.2 & 0.339 \\
\hline $\mathrm{T}$ & 4 & 48 & 47.8 & $<0.001^{* * * \times}$ \\
\hline $\mathrm{N} \times \mathrm{S}$ & 6 & 24 & 0.8 & 0.562 \\
\hline $\mathrm{N} \times \mathrm{T}$ & 8 & 48 & 1.4 & $0.253^{\mathrm{x}}$ \\
\hline $\mathrm{S} \times \mathrm{T}$ & 12 & 48 & 0.8 & $0.561^{\mathrm{x}}$ \\
\hline $\mathrm{N} \times \mathrm{S} \times \mathrm{T}$ & 24 & 48 & 0.7 & $0.729^{\mathrm{x}}$ \\
\hline
\end{tabular}

${ }^{\mathrm{z}}$ Factorial effects: $\mathrm{N}=$ nitrogen rate, $\mathrm{S}=$ secondary macronutrient, $\mathrm{T}=$ time. Time and interactions including time as a factor were corrected for sphericity.

${ }^{\mathrm{y}} \mathrm{df}=$ degrees of freedom; DDF $=$ denominator degrees of freedom.

${ }^{x}$ Probability value corrected with GreenhouseGeisser when sphericity assumption was not met. *, **, ***Significant at $P<0.05,0.01$, or 0.001 , respectively.

the $\mathrm{Ca}$ and $\mathrm{Mg}$ treatments were higher than the grower standard at $280 \mathrm{~kg} \cdot \mathrm{ha}^{-1} \mathrm{~N}$ (Fig. 1B). In Mar. 2020, the Mg treatment was higher than other treatments at $168 \mathrm{~kg} \cdot \mathrm{ha}^{-1} \mathrm{~N}$, whereas the $\mathrm{Ca}$ treatment was higher than the grower standard at $280 \mathrm{~kg} \cdot \mathrm{ha}^{-1} \mathrm{~N}$ (Fig. 1C). There were no significant differences among treatments in terms of canopy volume when expressed as percent change between 2018 and 2020, with no apparent differences among treatments at $168 \mathrm{~kg} \cdot \mathrm{ha}^{-1} \mathrm{~N}$, and a nonsignificant trend of greatest change in the Ca treatment $\left(224 \mathrm{~kg} \cdot \mathrm{ha}^{-1} \mathrm{~N}\right)$ or the grower standard treatment (280 kg.ha ${ }^{-1} \mathrm{~N}$, Fig. 1D).

Trunk cross-sectional area. TCSA was significantly affected by $\mathrm{N}$ rate $(P=0.036)$, secondary macronutrients $(P=0.01)$, the interaction between $\mathrm{N}$ rate and secondary macronutrients $(P=0.018)$, and time $(P=$ 0.039 ) (Table 2 ). Secondary macronutrients always had a statistically significant effect on TCSA except for Sept. 2019 (Table 3, Supplemental Tables 1 and 2). TCSA was significantly affected by $\mathrm{N}$ rates only in Sept. 2019 $(P=0.046)$, with no differences in Nov. 2018 $(P=0.076)$ and Mar. $2020(P=0.072)$. The $\mathrm{N}$ by macronutrient interaction was significant in Mar. $2018(P=0.032)$, Nov. 2018 $(P=0.049)$, and Mar. $2020(P=0.042)$, but not Mar. $2019(P=0.094)$.

In Mar. 2018, the Mg treatment was significantly higher than the $\mathrm{Ca}+\mathrm{Mg}$ treatment at $168 \mathrm{~kg} \cdot \mathrm{ha}^{-1} \mathrm{~N}$, and the $\mathrm{Ca}$ and $\mathrm{Mg}$ treatments were greater than the grower standard at $280 \mathrm{~kg} \cdot \mathrm{ha}^{-1} \mathrm{~N}$ (Fig. 2). In Mar. 2019, the $\mathrm{Mg}$ treatment was significantly higher than all other treatments at $168 \mathrm{~kg} \cdot \mathrm{ha}^{-1} \mathrm{~N}$. Patterns among treatments were the same in Mar. 2020 as in 2018.

Fruit yield. Fruit yield was not significantly influenced by $\mathrm{N}$ rates and secondary macronutrient treatments, although yields increased with time $(P<0.001)$ (Table 4$)$. N rates did not have a significant effect when yields were analyzed by date, although in April 2019, N rates had a marginally significant effect on yields $(P=0.090)$, with greater yields at $168 \mathrm{~kg} \cdot \mathrm{ha}^{-1} \mathrm{~N}$ and $224 \mathrm{~kg} \cdot \mathrm{ha}^{-1} \mathrm{~N}$ than $280 \mathrm{~kg} \cdot \mathrm{ha}^{-1} \mathrm{~N}$ (Table 4, Fig. 3).

Secondary macronutrient effects on yield were not statistically significant when tested within each $\mathrm{N}$ rate in both Mar. 2018 and 2019 (Fig. 3A and B). In Mar. 2020, the Ca and $\mathrm{Mg}$ treatments had $50 \%$ higher yield than the grower standard at $168 \mathrm{~kg} \cdot \mathrm{ha}^{-1} \mathrm{~N}$, whereas secondary macronutrients did not increase yield at the higher $\mathrm{N}$ rates. At 168 $\mathrm{kg} \cdot \mathrm{ha}^{-1} \mathrm{~N}$, the Ca treatment increased yield by $140 \%$ between 2018 and 2020, compared with $90 \%(\mathrm{Mg}+\mathrm{Ca})$ or $50 \%(\mathrm{Mg}$ and grower standard) for other treatments, although differences among treatments were not statistically significant (Fig. 3D). Percent yield change was similar among secondary macronutrient treatments at higher $\mathrm{N}$ rates, with no significant differences.

Juice quality. Secondary macronutrients significantly affected acidity $(P=0.004)$ and the TSS/acidity ratio $(P=0.006)$ in 2019 , in contrast to $\mathrm{N}$ rates or the interaction between $\mathrm{N}$ and secondary macronutrients (Table 5). Magnesium increased acidity by $10 \%$ compared with other secondary macronutrient treatments and decreased the TSS/acidity ratio relative to the grower standard and $\mathrm{Ca}+\mathrm{Mg}$ treatments (Table 5).

In 2020, there was no statistically significant effect of $\mathrm{N}$ rates, macronutrients, or interactions on acidity and/or TSS/acidity ratio (Table 5). However, TSS was significantly affected by secondary macronutrients $(P=0.03)$, with the $\mathrm{Mg}$ treatment having a $10 \%$ higher Brix compared with the $\mathrm{Ca}$ treatment (Fig. 4F).

\section{Discussion}

Citrus tree growth and development are severely affected by HLB (Atta et al., 2018; Morgan et al., 2016; Vashisth and Grosser, 2018). Although $\mathrm{N}$ and secondary macronutrient inputs mitigated the deleterious effects of HLB on vegetative growth of 'Hamlin' oranges in another study conducted in Florida (Atta, 2019), there was no clear effect of different $\mathrm{N}$ rates and secondary macronutrients on canopy volume in this experiment. This

Table 3. Analysis of variance for canopy volume and trunk cross-sectional area in Huanglongbing-affected 'Valencia' citrus trees between 2018 and 2020 , as affected by nitrogen rates and secondary macronutrients. For variables and dates with a significant interaction, results from Tukey tests are shown in Figs. 1 and 2.

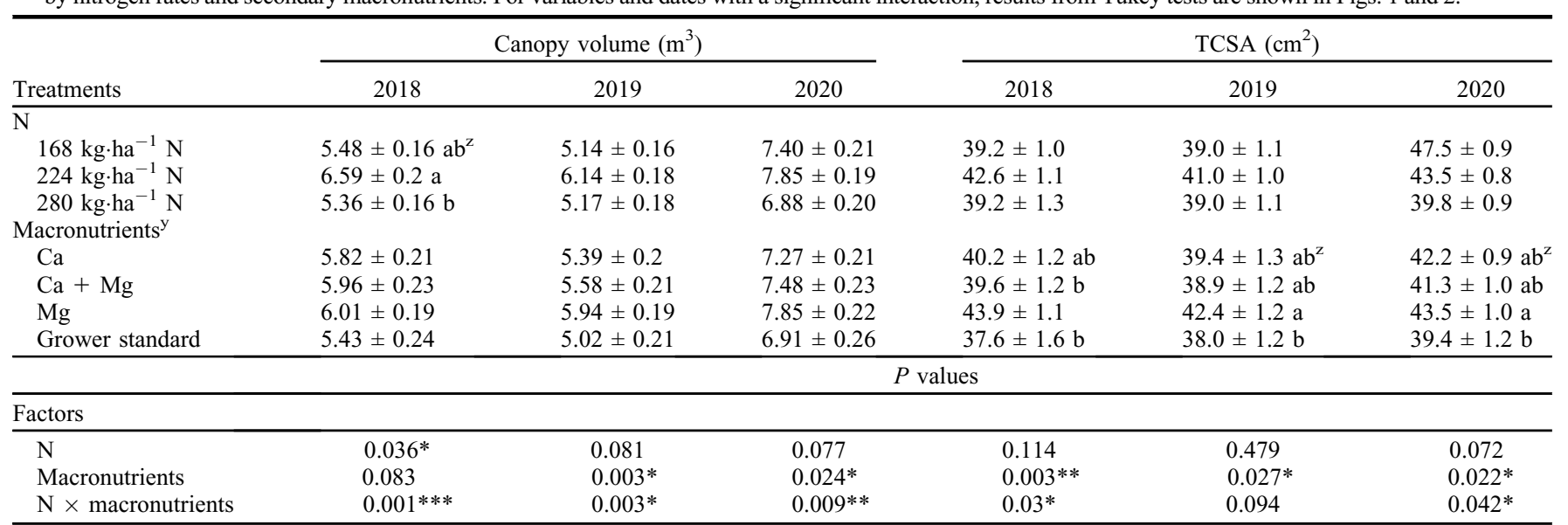

${ }_{\mathrm{z}}$ Means followed by the same letter within the same column of the nitrogen or macronutrient variate are not significantly different at $P<0.05$.

${ }^{\mathrm{y}} \mathrm{Ca}$ and $\mathrm{Mg}$ inputs: supplemental $\mathrm{Ca}\left(96 \mathrm{~kg} \cdot \mathrm{ha}^{-1}\right)+$ basal $\mathrm{Mg}\left(56 \mathrm{~kg} \cdot \mathrm{ha}^{-1}\right)$ for Ca; supplemental $\mathrm{Ca}\left(73.5 \mathrm{~kg} \cdot \mathrm{ha}^{-1}\right)+$ supplemental Mg $\left(78.5 \mathrm{~kg} \cdot \mathrm{ha}^{-1}\right)$ for $\mathrm{Ca}+\mathrm{Mg}$; basal $\mathrm{Ca}\left(51 \mathrm{~kg} \cdot \mathrm{ha}^{-1}\right)+$ supplemental $\mathrm{Mg}\left(101 \mathrm{~kg} \cdot \mathrm{ha}^{-1}\right)$ for $\mathrm{Mg}$; basal Ca $\left(51 \mathrm{~kg} \cdot \mathrm{ha}^{-1}\right)$ and basal Mg $\left(56 \mathrm{~kg} \cdot \mathrm{ha}{ }^{-1}\right)$ for grower standard. $*, * *, * *$ Significant at $P<0.05,0.01$, or 0.001 , respectively. 
A

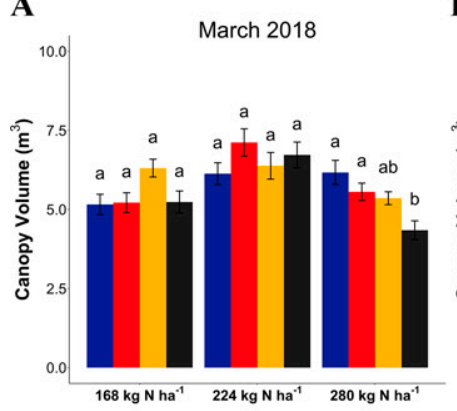

B

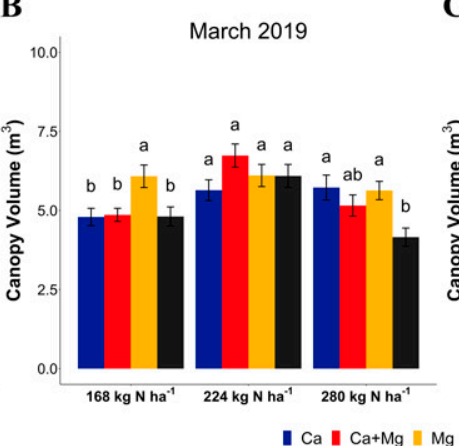

C

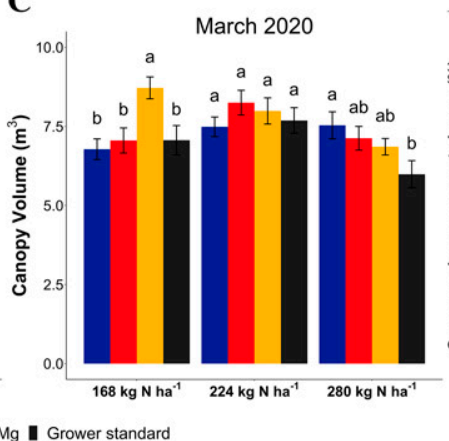

D

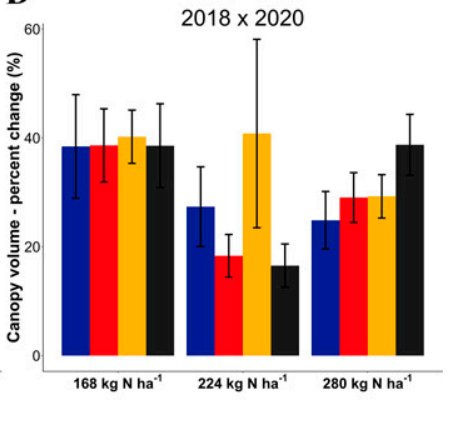

Fig. 1. The influence of nutrient inputs on the canopy volume of Huanglongbing-affected 'Valencia' citrus trees, by nitrogen rate, in (A) Mar. 2018, (B) Mar. 2019, and (C) Mar. 2020. Values were transformed from the square root. Bar plots represent mean of original data, and error bars represent standard errors. Letters should not be compared among nitrogen rates for any given date. Treatments sharing a given letter within each nitrogen rate are not statistically different based on Tukey's honestly significant difference at $P=0.05$. (D) Representation of canopy volume percentage change between Mar. 2018 and Mar. 2020. No letters are shown, as differences among treatments were not statistically significant. Error bars represent standard errors.

A

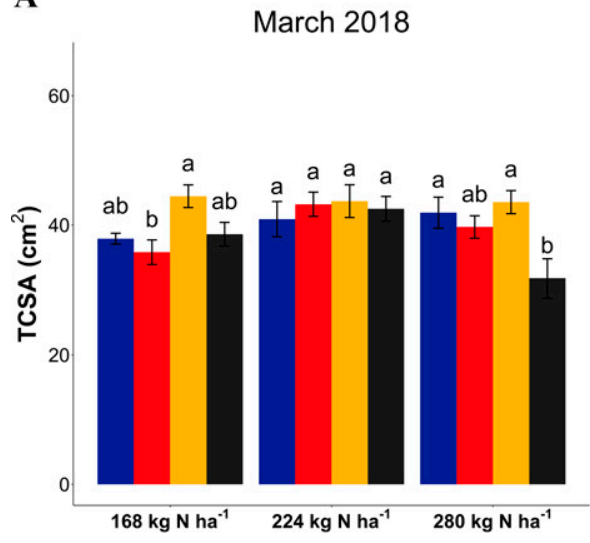

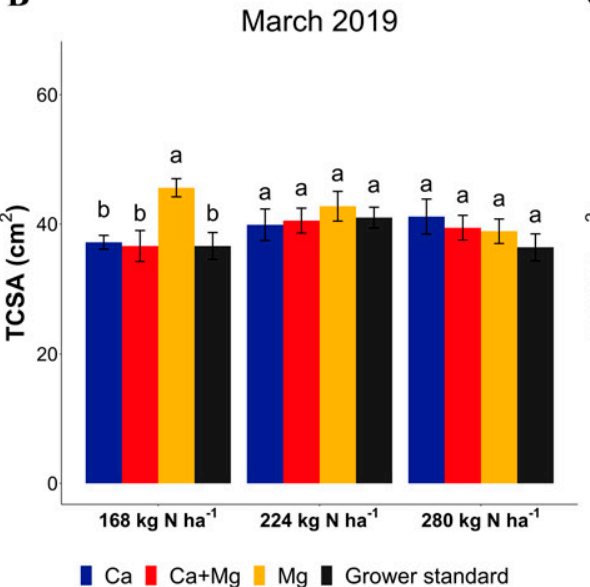

C

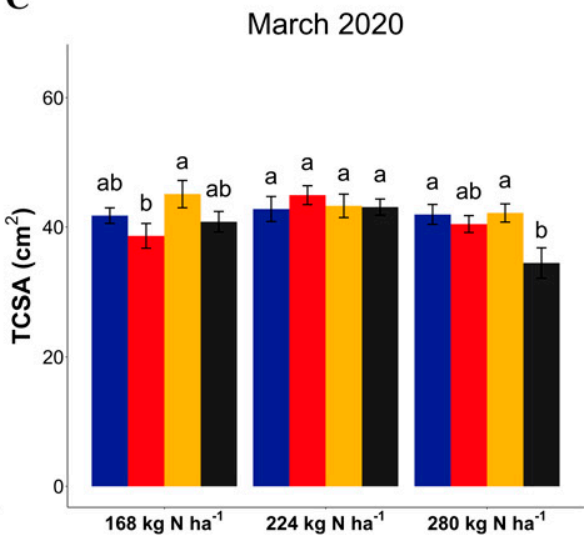

Fig. 2. The influence of nutrient inputs on trunk cross-sectional area (TCSA) of Huanglongbing-affected 'Valencia' citrus trees, by nitrogen rate, between 2018 and 2020. Values were transformed from the power scale. Bar plots represent mean of original data, and error bars represent standard errors. Letters should not be compared among nitrogen rates for any given date. Treatments sharing a given letter within each nitrogen rate are not statistically different based on Tukey's honestly significant difference at $P=0.05$.

could partly be because of preexisting differences in the trees used for this experiment as well as similar initial $\mathrm{N}$ concentrations among treatments. The lack of $\mathrm{N}$ effects could also be because of the use of soil-applied urea to achieve higher $\mathrm{N}$ rates in this experiment (ammonium nitrate was used in the basal fertilizer), as higher $\mathrm{N}$ rates when using urea could result in large volatilization losses (varying between $14 \%$ and $44 \%$ ) that would reduce or mask the differences observed among $\mathrm{N}$ rates (Cantarella et al., 2003; Mattos et al., 2003). At $168 \mathrm{~kg} \cdot \mathrm{ha}^{-1} \mathrm{~N}$, all the secondary macronutrient levels led to a $40 \%$ increase in canopy volume during the study period. In contrast, the increase was lower at other $\mathrm{N}$ rates, except for $\mathrm{Mg}$ at the $224 \mathrm{~kg} \cdot \mathrm{ha}^{-1} \mathrm{~N}$ and grower standard at the $280 \mathrm{~kg} \cdot \mathrm{ha}^{-1} \mathrm{~N}$, which were close to $40 \%$, suggesting there was a lower impact of secondary macronutrients on canopy volume at higher $\mathrm{N}$ rates.

Similar to our study, Morgan et al. (2009) did not find any significant difference among different $\mathrm{N}$ rates $(135,170,200,235,270$, and $300 \mathrm{~kg} \cdot \mathrm{ha}^{-1} \mathrm{~N}$ ) on 8- to 10 -year-old 'Ambersweet' orange trees on Swingle rootstock, at the same location as this experiment but with non-HLB-affected trees. Similarly, Uthman (2019) found no effect of similar $\mathrm{N}$ rates on canopy volume in a nearby experiment at the same site using the same citrus scion, rootstock, and planting density as this study, although they combined $\mathrm{N}$ applications with foliar and/or soil applications of micronutrients ( $\mathrm{Mn}, \mathrm{Zn}$, and B) instead of secondary macronutrients. Furthermore, Atta (2019) found no effects of similar $\mathrm{N}$ rates and secondary macronutrient treatments on canopy volume, with the same citrus variety and rootstock as used in this study for trees that were 5 years older, grown on a Spodosol, and with a lower planting density $(\approx 380$ trees/ha). These results are consistent with this study and suggest few, if any, benefits of increasing $\mathrm{N}$ inputs and/or supplying secondary macronutrients on canopy volume. In contrast, Atta (2019) did find that the $280 \mathrm{~kg} \cdot \mathrm{ha}^{-1} \mathrm{~N}$ rate significantly increased canopy volume of 'Hamlin' on Swingle rootstock, indicating that scion and rootstock selections can affect fertilization experiments of HLB-affected trees. Similarly, Phuyal et al. $(2020 \mathrm{a}, 2020 \mathrm{~b})$ found that higher $\mathrm{N}, \mathrm{Mg}$, and micronutrient inputs increased canopy volume of 'Ray Ruby' grapefruit on Kuharske citrange, although this occurred at the expense of fruit yield.

Although there was a significant effect of $\mathrm{N}$ rates and secondary macronutrients on TCSA, time was likely the only factor that had a real impact on TCSA. As with canopy volume, differences in $\mathrm{N}$ rates and secondary macronutrients may be due to preexisting differences in trees before the start of this experiment. These findings are consistent with the lack of effect reported by Uthman (2019), with similar $\mathrm{N}$ rates using 'Valencia' on Swingle rootstock. In HLB-free trees, Calvert (1970) found no significant difference in trunk circumference of 'Temple' oranges with applications of dolomitic lime, which is a low-solubility source of Mg. Ultimately, as citrus grows slowly, it is possible that the effects of nutrition on vegetative growth were not yet quantifiable given the short duration of this study.

Vincent et al. (2020) recommended planting densities for citrus between 400 and 745 trees/ha in Florida, acknowledging that increasing planting density may not increase yield at grove maturity. The high planting density used in this study (1111 trees/ha) 
Table 4. Analysis of variance for yield in Huanglongbing-affected 'Valencia' citrus trees between 2018 and 2020, as affected by nitrogen $(\mathrm{N})$ rates and secondary macronutrients.

\begin{tabular}{llcr}
\hline & \multicolumn{3}{c}{ Fruit yield per area $\left(\mathrm{kg} \cdot \mathrm{ha}^{-1}\right)$} \\
\cline { 2 - 4 } Treatments & $2017-18$ & $2018-19$ & $2019-20$ \\
\hline $\mathrm{N}$ & & & $2920 \pm 193$ \\
$168 \mathrm{~kg} \cdot \mathrm{ha}^{-1} \mathrm{~N}$ & $1763 \pm 189$ & $2157 \pm 193$ & $2820 \pm 146$ \\
$224 \mathrm{~kg} \cdot \mathrm{ha}^{-1} \mathrm{~N}$ & $1928 \pm 153$ & $2296 \pm 167$ & $2599 \pm 131$ \\
$280 \mathrm{~kg} \cdot \mathrm{ha}^{-1} \mathrm{~N}$ & $1717 \pm 93$ & $1644 \pm 119$ & $2892 \pm 207$ \\
$\mathrm{Macronutrients}$ & & & $2676 \pm 118$ \\
$\mathrm{Ca}$ & $1673 \pm 191$ & $1827 \pm 192$ & $2578 \pm 238$ \\
$\mathrm{Ca}+\mathrm{Mg}$ & $1835 \pm 145$ & $1947 \pm 135$ & $2974 \pm 147$ \\
$\mathrm{Mg}$ & $1751 \pm 148$ & $1982 \pm 158$ & $2372 \pm 289$ \\
$\mathrm{Grower} \mathrm{standard}$ & $1953 \pm 209$ & $P$ values & \\
\hline & & & 0.589 \\
\hline Factors & & 0.090 & 0.274 \\
$\mathrm{~N}$ & 0.642 & 0.211 & 0.236 \\
$\mathrm{~N}$ & 0.733 & 0.787 & \\
\hline
\end{tabular}

${ }^{\mathrm{z}}$ Calcium (Ca) and magnesium (Mg) inputs: supplemental Ca $\left(96 \mathrm{~kg} \cdot \mathrm{ha}^{-1}\right)+$ basal $\mathrm{Mg}\left(56 \mathrm{~kg} \cdot \mathrm{ha}^{-1}\right)$ for Ca; supplemental $\mathrm{Ca}\left(73.5 \mathrm{~kg} \cdot \mathrm{ha}^{-1}\right)+$ supplemental $\mathrm{Mg}\left(78.5 \mathrm{~kg} \cdot \mathrm{ha}^{-1}\right)$ for Ca $+\mathrm{Mg}$; basal Ca $\left(51 \mathrm{~kg} \cdot \mathrm{ha}^{-1}\right)+$ supplemental $\mathrm{Mg}\left(101 \mathrm{~kg} \cdot \mathrm{ha}^{-1}\right)$ for $\mathrm{Mg}$; basal Ca $\left(51 \mathrm{~kg} \cdot \mathrm{ha}^{-1}\right)$ and basal $\mathrm{Mg}\left(56 \mathrm{~kg} \cdot \mathrm{ha}^{-1}\right)$ for grower standard. might have masked the effects of plant nutrition on vegetative growth variables, as higher densities promote higher competition among nutrients, water, space, and light, which may affect vegetative growth (Weil and Brady, 2017). This is supported by the findings of Phuyal et al. (2020a, 2020b) who observed lower canopy volume and trunk diameter with a high planting density (975 trees/ha) when compared with lower planting densities of (300 and 440 trees/ha) of 'Ray Ruby' grapefruit on Kuharske citrange. However, they found greater fruit yield per hectare with the highest planting density, with no significant yield difference among fertilizer treatments.

There was no effect of $\mathrm{N}$ rates or secondary macronutrients on yield in this study, similar to Uthman (2019), who found a marginally significant effect of $\mathrm{N}$ rate on yield. Quaggio et al. (2019) also found no difference between two $\mathrm{N}$ rates $\left(120 \mathrm{~kg} \cdot \mathrm{ha}^{-1} \mathrm{~N}\right.$ and $240 \mathrm{~kg} \cdot \mathrm{ha}^{-1}$ $\mathrm{N})$ in an irrigated system with 4-year-old
A

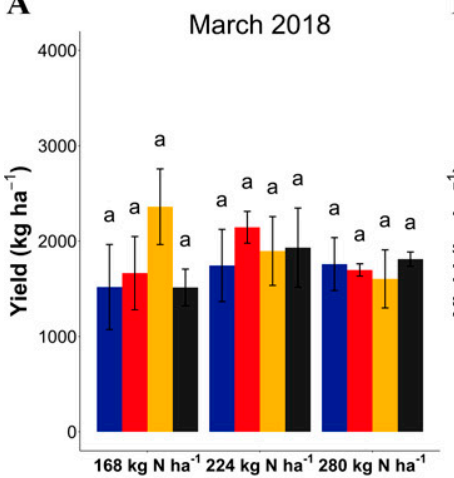

B

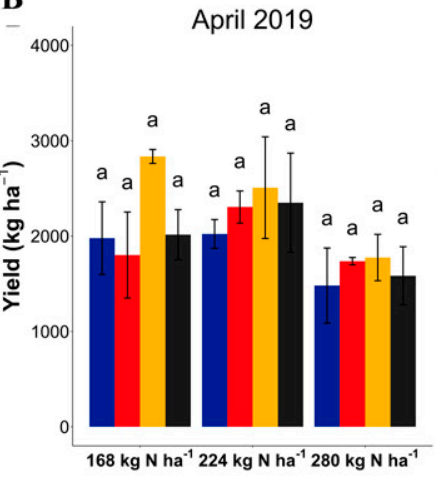

C

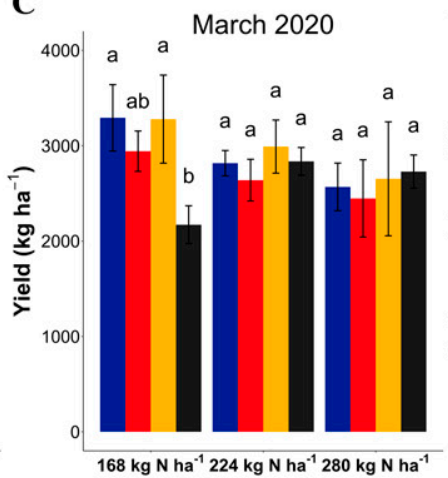

D

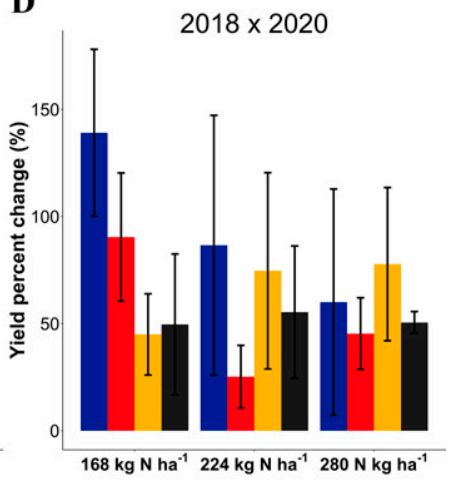

【Ca $\|\mathrm{Ca}+\mathrm{Mg}\| \mathrm{Mg} \|$ Grower standard

Fig. 3. The effect of secondary macronutrients on yield of Huanglongbing-affected 'Valencia' citrus tree by nitrogen rate in 2018 (A), 2019 (B), and 2020 (C). Bar plots represent mean of original data, and error bars represent standard errors. Letters should not be compared among $\mathrm{N}$ rates for each given date. No letters are shown in Mar. 2018 or April 2019, as differences among treatments were not statistically significant. Treatments sharing a given letter within each nitrogen rate are not statistically different based on Tukey's honestly significant difference at $P=0.05$. (D) Representation of effect of plant nutrition on the percentage change of yield for Huanglongbing-affected trees between 2018 and 2020. No letters are shown, as differences among treatments were not statistically significant. Error bars represent standard errors.

Table 5. Analysis of variance for juice quality in Huanglongbing-affected 'Valencia' citrus trees between 2018 and 2020, as affected by nitrogen (N) rates and secondary macronutrients.

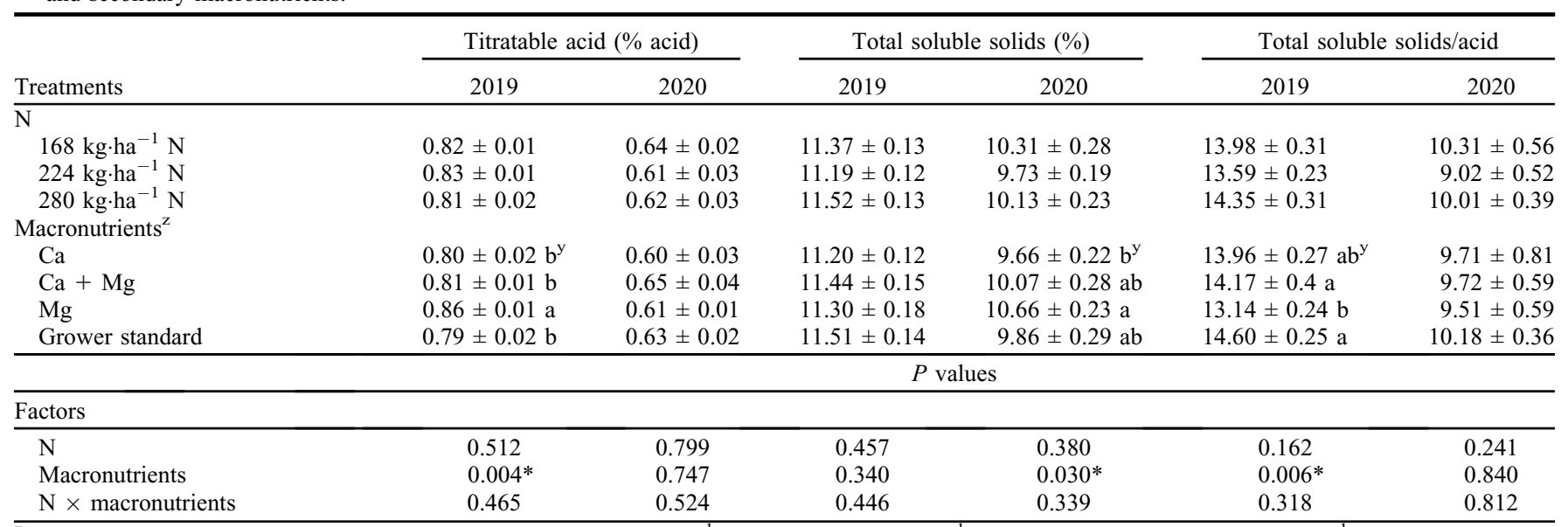

${ }^{\bar{z}}$ Calcium (Ca) and magnesium (Mg) inputs: supplemental Ca $\left(96 \mathrm{~kg} \cdot \mathrm{ha}^{-1}\right)+$ basal $\mathrm{Mg}\left(56 \mathrm{~kg} \cdot \mathrm{ha}^{-1}\right)$ for Ca; supplemental Ca $\left(73.5 \mathrm{~kg} \cdot \mathrm{ha}{ }^{-1}\right)+\mathrm{supplemental} \mathrm{Mg}$ $\left(78.5 \mathrm{~kg} \cdot \mathrm{ha}^{-1}\right)$ for $\mathrm{Ca}+\mathrm{Mg}$; basal Ca $\left(51 \mathrm{~kg} \cdot \mathrm{ha}^{-1}\right)+$ supplemental $\mathrm{Mg}\left(101 \mathrm{~kg} \cdot \mathrm{ha}^{-1}\right)$ for $\mathrm{Mg}$; basal Ca $\left(51 \mathrm{~kg} \cdot \mathrm{ha}^{-1}\right)$ and basal Mg $\left(56 \mathrm{~kg} \cdot \mathrm{ha}^{-1}\right)$ for grower standard.

${ }^{\mathrm{y}}$ Means followed by the same letter with the same column of the nitrogen or macronutrient variate are not significantly different at $P<0.05$.

*Significant at $P<0.05$. 
A

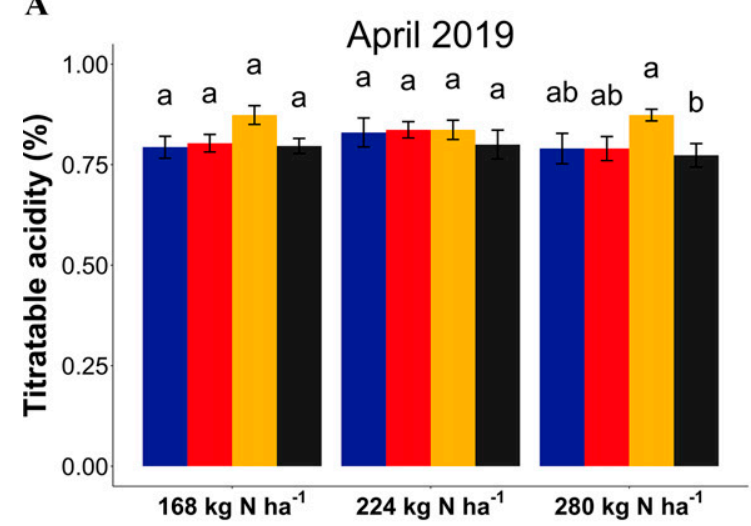

C

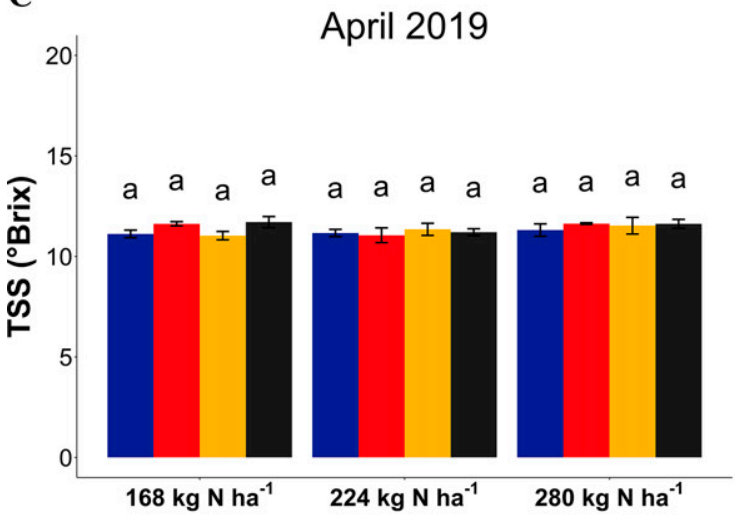

B

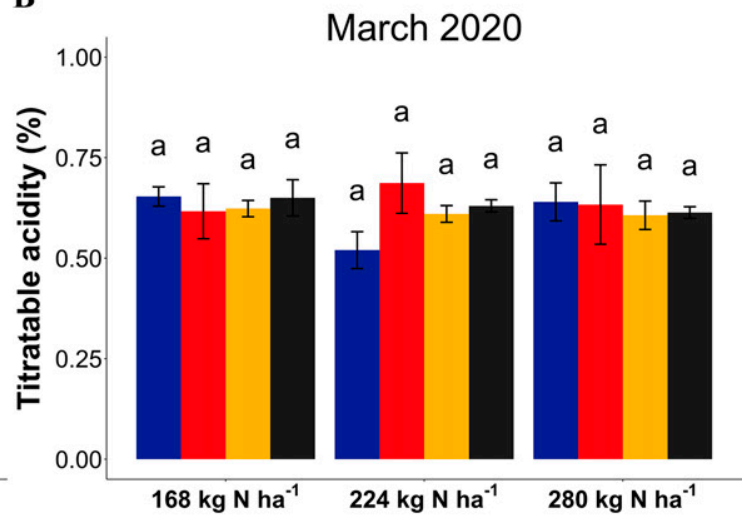

D

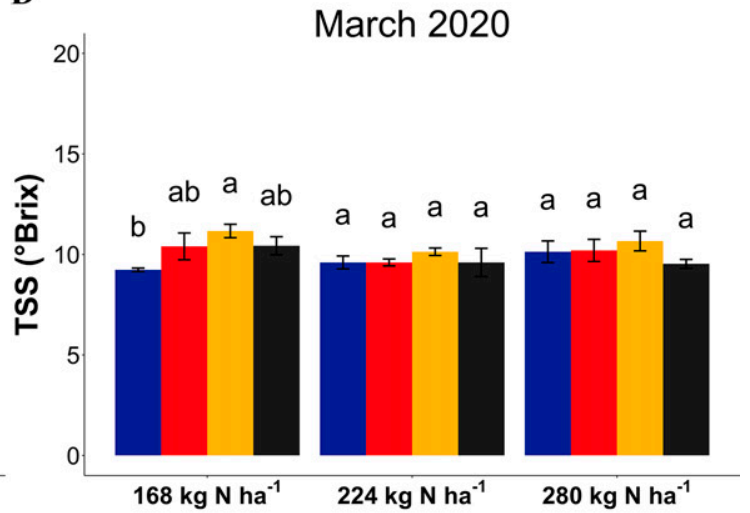

$\mathbf{E}$

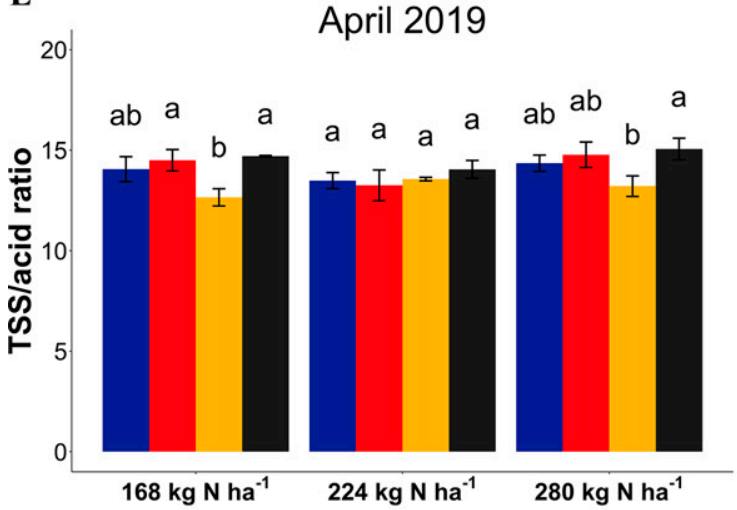

F

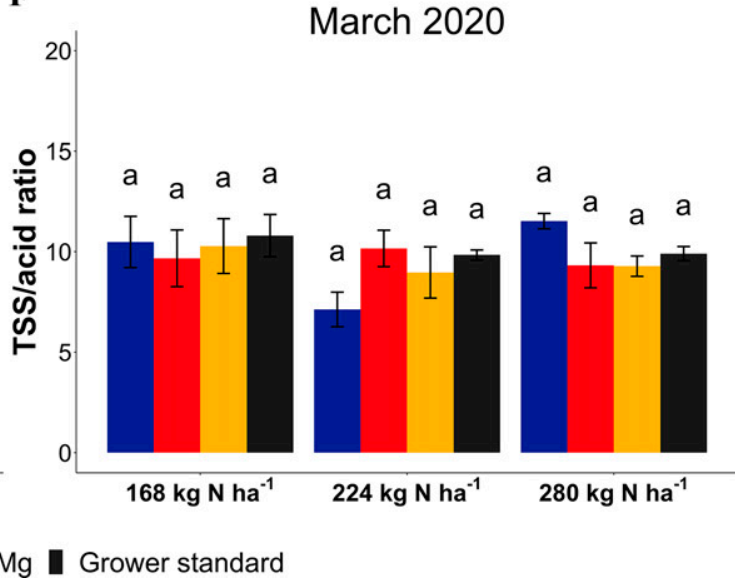

Fig. 4. The effect of secondary macronutrients on juice quality variables of Huanglongbing-affected orange trees. Bar plots represent mean of original data, and error bars represent standard errors. Letters should not be compared among nitrogen $(\mathrm{N})$ rates for each given date. Treatments sharing a given letter within each $\mathrm{N}$ rate are not statistically different based on Tukey's honestly significant difference at $P=0.05$.

'Natal' sweet orange grafted on Rangpur lime. Increasing $\mathrm{N}$ inputs beyond the recommended $224 \mathrm{~kg} \cdot \mathrm{ha}^{-1} \mathrm{~N}$ rate resulted in no yield benefit in this study, which could be due to higher $\mathrm{N}$ rates causing $\mathrm{NH}_{4}$ toxicity that would negatively affect the performance of citrus trees (Quaggio et al., 2019). Although not significant, there was a decreasing trend in fruit yield with increasing $\mathrm{N}$ rate, similar to the data reported by Schumann et al. (2003) for healthy trees, warranting further investigation in HLBaffected trees. The highest percentage change in yield was obtained with $\mathrm{Ca}$ and $\mathrm{Ca}+\mathrm{Mg}$ at $168 \mathrm{~kg} \cdot \mathrm{ha}^{-1} \mathrm{~N}$, with a lower percentage change in yield at higher $\mathrm{N}$ rates. Although this interaction was not statistically significant in this study, these results suggest a potentially positive interaction between $\mathrm{N}$ and $\mathrm{Ca}$ that could increase yield. Higher yields at high $\mathrm{N}$ rates can be achieved by maintaining $\mathrm{N}: \mathrm{Ca}$ and/or $\mathrm{N}: \mathrm{Mg}$ ratios at optimal levels in plant tissue, suggesting a balanced input of $\mathrm{Ca}$ and $\mathrm{Mg}$ as $\mathrm{N}$ increases. Moda et al. (2021) found that an optimal $\mathrm{NO}_{3}: \mathrm{NH}_{4}$ ratio could mitigate ammoniacal toxicity in citrus seedlings, which might otherwise occur when $\mathrm{N}$ rates increase, and this ratio is altered. Overall, the interaction between $\mathrm{N}$ and $\mathrm{Ca}$ should be more thoroughly investigated in future studies, to determine if $\mathrm{N}$ rates could be reduced without compromising fruit yields.

There was no clear pattern regarding the effect of $\mathrm{N}$ and secondary macronutrients on orange juice quality. In 2020, the Mg treatment had significantly higher TSS compared with $\mathrm{Ca}$, consistent with Quaggio et al. (1992) who found higher TSS after applying $\mathrm{Mg}$ to 'Valencia' on Rangpur lime, and Koo (1988) who reported slight increases in TSS in orange juice with applications of both $\mathrm{N}$ and $\mathrm{Mg}$. Juice acidity increased and the TSS/acidity ratio decreased with $\mathrm{Mg}$ fertilization in 2019, similar to the results obtained by Quaggio et al. (1992); however, Weir (1969), Calvert (1970), and Koo (1971) did not find a significant effect of $\mathrm{Mg}$ on juice acidity in the pre-HLB era. Quiñones et al. (2012) reported lower acidity and soluble solids content with $\mathrm{Mg}$ deficiency, and Moss and Higgins (1974) found a positive 
relationship between fruit juice acidity and $\mathrm{Mg}$ applications in 'Washington Navel' and 'Late Valencia' oranges. Applying Mg may increase the acidity of oranges by reducing $\mathrm{Ca}$ uptake from the soil (Moss and Higgins, 1974; Quaggio et al., 1992). $\mathrm{N}$ and/or Ca applications did not affect juice acidity in this study, similar to Morgan et al. (2009), who reported that different $\mathrm{N}$ rates had no effect on juice acidity for 'Ambersweet' oranges grafted on Swingle rootstock.

Overall, the $\mathrm{N}$ rates used in this study had no significant effect on yield, vegetative growth, and juice quality. This suggests that $\mathrm{N}$ rates could likely be reduced to $168 \mathrm{~kg} \cdot \mathrm{ha}^{-1} \mathrm{~N}$ in HLB-affected citrus without negative impacts, as supported by other studies conducted in Florida that came to similar conclusions (Atta, 2019; Uthman, 2019). This is especially true if secondary macronutrients are included in the nutritional program as well, as there were benefits of secondary macronutrients at the lowest $\mathrm{N}$ rate in this study. However, given that treatments were monitored for only 2 years, the effects of these nutrients should be confirmed with longer-term studies conducted at multiple sites. Furthermore, as urea was used as a fertilizer to achieve higher $\mathrm{N}$ rates, and ammonia volatilization losses were not measured in this study; it is critical to determine the results of high $\mathrm{N}$ input rates when using fertilizers that are not prone to volatilization losses.

\section{Literature Cited}

Alvarez, S., E. Rohrig, D. Solís, and M.H. Thomas. 2016. Citrus greening disease (Huanglongbing) in Florida: Economic impact, management, and the potential for biological control. Agr. Res. 5:109-118.

Anderson, D. and L. Henderson. 1988. Comparing sealed chamber digestion with other digestion methods used for plant-tissue analysis. Agron. J. 80:549-552.

Atta, A.A. 2019. Citrus nutrient management on huanglongbing (citrus greening) affected citrus groves on Florida sandy soils. Univ. Fla., Gainesville, PhD. Diss.

Atta, A.A., K.T. Morgan, S.A. Hamido, and D.M. Kadyampakeni. 2020. Effect of essential nutrients on roots growth and lifespan of huanglongbing affected citrus trees. Plants 9:483. doi: $10.3390 /$ plants 9040483 .

Atta, A.A., K.T. Morgan, D.M. Kadyampakeni, and M.A. Kamal. 2018. Effect of soil and/or foliar applied nutrients on leaf nutrient accumulation and water uptake on huanglongbing affected 'Valencia' citrus trees. Proc. Annu. Meet. Fla. State Hort. Soc. 131:58-64.

Bassanezi, R.B., L.E. Montesino, M.C.G. Gasparoto, A.B. Filho, and L. Amorim. 2011. Yield loss caused by huanglongbing in different sweet orange cultivars in São Paulo, Brazil. Eur. J. Plant Pathol. 130:577-586.

Bassanezi, R.B., L.E. Montesino, and E.S. Stuchi. 2009. Effects of huanglongbing on fruit quality of sweet orange cultivars in Brazil. Eur. J. Plant Pathol. 125:565-572.

Bové, J.M. 2006. Huanglongbing: A destructive, newly-emerging, century-old disease of citrus. J. Plant Pathol. 88:7-37.

Calvert, D.V. 1970. Response of "Temple" oranges to varying rates of nitrogen, potassium, and magnesium. Proc. Annu. Meet. Fla. State Hort. Soc. 83:10-15.

Cantarella, H., D. Mattos, J.A. Quaggio, and A.T. Rigolin. 2003. Fruit yield of Valencia sweet orange fertilized with different $\mathrm{N}$ sources and the loss of applied N. Nutr. Cycl. Agroecosyst. 67(3):215-223.

Dagulo, L., M.D. Danyluk, T.M. Spann, M.F. Valim, R. Goodrich-Schneider, C. Sims, and R. Rouseff. 2010. Chemical characterization of orange juice from trees infected with citrus greening (huanglongbing). J. Food Sci. 75:199-207.

Dala-Paula, B.M., A. Plotto, J. Bai, J.A. Manthey, E.A. Baldwin, R.S. Ferrarezi, and M.B. Gloria. 2019. Effect of Huanglongbing or greening disease on orange juice quality, a review. Front. Plant Sci. 9:1-19.

Florida Department of Agriculture and Consumer Services. 2020. Florida Citrus Statistics 20182019. Tallahassee, FL.

García-Mina, J.M. 2012. Plant nutrition and defense mechanism: Frontier knowledge, p. 477. In: A.K. Srivastava (ed.). Advances in citrus nutrition. Springer, Dordrecht.

Graham, J.H., E.G. Johnson, T.R. Gottwald, and M.S. Irey. 2013. Presymptomatic fibrous root decline in citrus trees caused by huanglongbing and potential interaction with Phytophthora spp. Plant Dis. 97:1195-1199.

Handique, U., R.C. Ebel, and K.T. Morgan. 2012. Influence of soil-applied fertilizer on greening development in new growth flushes of sweet orange. Proc. Annu. Meet. Fla. State Hort. Soc. 125:36-39.

Hanlon, E.A., J.S. Gonzalez, and J.M. Bartos. 1997. Institute of Food and Agricultural Sciences (IFAS) Extension Soil Testing Laboratory (ESTL) and Analytical Research Laboratory (ARL) chemical procedures and training manual. Gainesville, FL.

Hart, W.E. and L.D. Gaultney. 1991. Citrus tree spacing effects on soil water use, root density, and fruit yield. Trans. Amer. Soc. Agr. Eng. 34:129-0134.

Hawkesford, M., W. Horst, T. Kichey, H. Lambers, J. Schjoerring, I. Skrumsager, and P. White. 2012. Functions of macronutrients, p. 651. In: P. Marschner (ed.). Mineral nutrition of higher plants. Elsevier, Academic Press, London.

Huber, D.M. and J.B. Jones. 2013. The role of magnesium in plant disease. Plant Soil 368:73-85.

Kadyampakeni, D.M., K.T. Morgan, P. NkediKizza, and G.N. Kasozi. 2015. Nutrient management options for Florida citrus: A review of NPK application and analytical methods. J. Plant Nutr. 38:568-583, doi: 10.1080/0190 4167.2014.934470.

Kadyampakeni, D.M., K.T. Morgan, and A.W. Schumann. 2016. Citrus fertigation and irrigation practices for managing HLB in Florida. Proc. Florida State Hort. Soc. 129:64-68.

Kadyampakeni, D.M., K.T. Morgan, A.W. Schumann, and P. Nkedi-Kizza. 2014. Effect of irrigation pattern and timing on root density of young citrus trees infected with huanglongbing disease. HortTechnology 24:209-221.

Kadyampakeni, D.M., K.T. Morgan, M. Zekri, R.S. Ferrarezi, A.W. Schumann, and T.A. Obreza. 2018. Irrigation management of citrus trees, p. 47-50. In: L.M. Diepenbrock, M.M. Dewdney, and T. Vashisth (eds.). Florida citrus production guide. Univ. of Florida Coop. Ext. Serv., Gainesville, FL.

Koo, R.C. 1971. A comparison of magnesium sources for citrus. Proc. Soil Crop Sci. Soc. Fla. 31:137-140.

Koo, R.C.J. 1988. Fertilization and irrigation effects on fruit quality, p. 35-42. In: J.J. Ferguson and
W.F. Wardowski (eds.). Factors affecting fruit quality - citrus short course. Proc. Fla. Coop. Extension Serv., Gainesville, FL.

Li, W., J.S. Hartung, and L. Levy. 2006. Quantitative real-time PCR for detection and identification of Candidatus Liberibacter species associated with citrus huanglongbing. J. Microbiol. Methods 66:104-115.

Mattos, D., A.K. Alva, S. Paramasivam, and D.A. Graetz. 2003. Nitrogen volatilization and mineralization in a sandy entisol of Florida under citrus. Commun. Soil Sci. Plant Anal. 34(1314):1803-1824.

Moda, L.R., R. de Mello Prado, J.P. de Souza Júnior, G.B. da Silva Júnior, L.C.N. dos Santos, M.V.G. Soares, and D.M. Kadyampakeni. 2021. Response of orange seedlings to the proportion of nitrate-ammonium in the nutrient solution and the benefits of phosphorus in ammonia toxicity. Scientia Hort. 285:110166, doi: 10.1016/j. scienta.2021.110166.

Morgan, K.T., T.A. Obreza, and J.M.S. Scholberg. 2007. Orange tree fibrous root length distribution in space and time. J. Amer. Soc. Hort. Sci. 132:262-269.

Morgan, K.T., R.E. Rouse, and R.C. Ebel. 2016. Foliar applications of essential nutrients on growth and yield of Valencia sweet orange infected with huanglongbing. HortScience 51: 1482-1493.

Morgan, K.T., J.M.S. Scholberg, T.A. Obreza, and T.A. Wheaton. 2006. Size, biomass, and nitrogen relationships with sweet orange tree growth. J. Amer. Soc. Hort. Sci. 131:149-156.

Morgan, K.T., T.A. Wheaton, W.S. Castle, and L.R. Parsons. 2009. Response of young and maturing citrus trees grown on a sandy soil to irrigation scheduling nitrogen fertilizer rate and nitrogen application method. HortScience 44:145-150.

Moss, G.I. and M.L. Higgins. 1974. Magnesium influences on the fruit quality of sweet orange. Plant Soil 41:103-112.

Munter, R., T. Halverson, and R. Anderson. 1984. Quality assurance for plant-tissue analysis by ICP-AES. Commun. Soil Sci. Plant Anal. 15: 1285-1322.

Obreza, T.A. and K.T. Morgan (eds.). 2008. Nutrition of Florida citrus trees, $2^{\text {nd }}$ edition, SL253, Univ. Fla. Coop. Ext. Serv., Gainesville, FL.

Obreza, T.A. and R.E. Rouse. 1993. Fertilizer effects on early growth and yield of "Hamlin" orange trees. HortScience 28:111-114.

Phuyal, D., T.A. Rodrigues Nogueira, A.D. Jani, D.M. Kadyampakeni, K.T. Morgan, and R. Ferrarezi. 2020a. 'Ray Ruby' grapefruit affected by huanglongbing I. Planting density and soil nutrient management. HortScience 55:14111419, doi: 10.21273/HORTSCI15111-20.

Phuyal, D., T.A. Rodrigues Nogueira, A.D. Jani, D.M. Kadyampakeni, K.T. Morgan, and R. Ferrarezi. 2020b. 'Ray Ruby' grapefruit affected by huanglongbing II. Planting density, soil, and foliar nutrient management. HortScience 55:1420 1432, doi: 10.21273/HORTSCI15255-20.

Plank, C.O. 1992. Plant analysis reference procedures for the southern region of the United States. Southern Coop. Ser. Bull. 368. University of Georgia, Crop and Soil Science Department, Athens, GA.

Quaggio, J.A., J.T. Sobrinho, and A.R. Dechen. 1992. Magnesium influences on fruit yield and quality of Valencia sweet orange on Rangpur lime. Proc. Intl. Soc. Citricult. 2:633-637.

Quaggio, J.A., T.R. Souza, F.C.B. Zambrosi, R.M Boaretto, and D. Mattos, Jr. 2014. Nitrogenfertilizer forms affect the nitrogen-use efficiency in fertigated citrus groves. J. Plant Nutr. Soil Sci. 177:404-411. 
Quaggio, J.A., T.R. Souza, F.C.B. Zambrosi, D. Mattos, R.M. Boaretto, and G. Silva. 2019. Citrus fruit yield response to nitrogen and potassium fertilization depends on nutrient-water management system. Scientia Hort. 249:329-333.

Quiñones, A., B. Martínez-Alcántara, E. PrimoMillo, and F. Legaz. 2012. Fertigation: Concept and application in citrus, p. 281-301. In: A.K Srivastava (ed.). Advances in citrus nutrition. Springer, Dordrecht.

R Core Team. 2017. R: A language and environment for statistical computing. Vienna, Austria.

Rouse, R., M. Irey, T. Gast, M. Boyd, and T. Willis. 2012. Fruit production in a southwest Florida citrus grove using the Boyd nutrient/SAR foliar spray. Proc. Annu. Meet. Fla. State Hort. Soc. 125:61-64.

Schumann, A.W., A. Fares, A. Alva, and S. Paramasivam. 2003. Response of Hamlin orange to fertilizer source, rate, and irrigated area. Proc. Annu. Meet. Fla. State Hort. Soc. 116:256-260.

Shahzad, F., C. Chun, A. Schumann, and T. Vashisth. 2020. Nutrient uptake in huanglongbing-affected sweet orange: Transcriptomic and physiological analysis. J. Amer. Soc. Hort. Sci. 145(6):349-362.

Spann, T. and A. Schumann. 2010. Mineral nutrition contributes to plant disease and pest resistance, EDIS, 2010(4). 30 Aug. 2020. < https://journals. flvc.org/edis/article/view/118663>.
Sétamou, M., C.R. Simpson, O.J. Alabi, S.D. Nelson, S. Telagamsetty, and J.L. Jifon. 2016. Quality matters: Influences of citrus flush physicochemical characteristics on population dynamics of the Asian citrus psyllid (Hemiptera: Liviidae). PLoS One 11:1-18.

Uthman, Q.O. 2019. Fate and transport of boron, manganese and zinc in citrus grown on Florida sandy entisol. Univ. Fla., Gainesville, MS Thesis. doi: 10.1017/CBO9781107415324.004.

Uthman, Q.O., D.M. Kadyampakeni, and P. NkediKizza. 2020a. Boron availability and uptake in huanglongbing-affected citrus trees on a Florida entisol. J. Plant Nutr. 43:1248-1258.

Uthman, Q.O., D.M. Kadyampakeni, and P. Nkedi-Kizza. 2020b. Manganese adsorption, availability, and uptake in citrus under microsprinkler irrigation. Agrosystems. Geosci. Environ. 3:1-8.

Vang-Petersen, O. 1980. Calcium, potassium and magnesium nutrition and their interactions in "Cox's orange" apple trees. Scientia Hort. 12: 153-161.

Vashisth, T. and J. Grosser. 2018. Comparison of controlled release fertilizer (CRF) for newly planted sweet orange trees under huanglongbing prevalent conditions. J. Hort. 5:3-7.

Vashisth, T., M. Zekri, and F. Alferez. 2020. Canopy management for young trees, p. 111-114. In: L.M. Diepenbrock, M.M. Dewdney, and T.
Vashisth (eds.). 2019-2020 Florida Citrus Production Guide. Univ. Fla. Coop. Ext. Serv., Gainesville, FL.

Vincent, C., T. Vashisth, M. Zekri, and U. Albrecht. 2020. Grove planning and establishment, p. 1-6. In: L.M. Diepenbrock, M.M. Dewdney, and T. Vashisth (eds.). 2019-2020 Florida Citrus Production Guide. Univ. Fla. Coop. Ext. Serv., Gainesville, FL.

Wardowski, W., J. Whigham, W. Grierson, and J. Soule. 1995. Quality tests for Florida citrus. Univ. Fla Coop. Ext. Serv., Gainesville, FL.

Weil, R.R. and N.C. Brady. 2017. The nature and properties of soils. 15th ed. Pearson, Essex, UK.

Weir, C.C. 1969. Potassium and magnesium nutrition of citrus trees. Trop. Agr. Trin. 46:131-136.

Zambon, F.T., D.M. Kadyampakeni, and J.W. Grosser. 2019. Ground application of overdoses of manganese have a therapeutic effect on sweet orange trees infected with Candidatus Liberibacter asiaticus. HortScience 54:1077-1086.

Zekri, M. 2016. The critical importance of citrus tree nutrition. 1st ed. AgNet Media, Gainesville, FL.

Zhou, Y., W. He, W. Zheng, Q. Tan, Z. Xie, C. Zheng, and C. Hu. 2018. Fruit sugar and organic acid were significantly related to fruit $\mathrm{Mg}$ of six citrus cultivars. Food Chem. 259:278-285. 
Supplemental Table 1. Analysis of variance for canopy volume and trunk cross-sectional area in Huanglongbing-affected 'Valencia' citrus trees in Nov. 2018 and Sept. 2019, as affected by nitrogen (N) rates and secondary macronutrients.

\begin{tabular}{|c|c|c|c|c|}
\hline Treatments & \multicolumn{2}{|c|}{ Canopy volume $\left(\mathrm{m}^{3}\right)$} & \multicolumn{2}{|c|}{$\operatorname{TCSA}\left(\mathrm{cm}^{2}\right)$} \\
\hline \multicolumn{5}{|l|}{$\mathrm{N}$} \\
\hline $280 \mathrm{~kg} \cdot \mathrm{ha}^{-1} \mathrm{~N}$ & $5.68 \pm 0.18$ & $6.79 \pm 0.19$ & $40.2 \pm 1.1$ & $39.9 \pm 1.2 \mathrm{~b}$ \\
\hline \multicolumn{5}{|l|}{ Macronutrients ${ }^{\mathrm{z}}$} \\
\hline $\mathrm{Ca}$ & $6.20 \pm 0.21$ & $7.41 \pm 0.24$ & $41.8 \pm 1.1$ & $42.2 \pm 1.2$ \\
\hline Grower standard & $5.71 \pm 0.23$ & $6.80 \pm 0.25$ & $39.1 \pm 1.3$ & $40.6 \pm 1.2$ \\
\hline & \multicolumn{4}{|c|}{$P$ values } \\
\hline \multicolumn{5}{|l|}{ Factors } \\
\hline $\mathrm{N}$ & 0.066 & $0.044 *$ & 0.076 & $0.046^{*}$ \\
\hline Macronutrients & $0.028^{*}$ & $0.011^{*}$ & $0.006^{*}$ & 0.099 \\
\hline $\mathrm{N} \times$ macronutrients & $0.002 *$ & $0.008^{* *}$ & $0.05^{*}$ & 0.246 \\
\hline
\end{tabular}

$\mathrm{Ca}=$ calcium; $\mathrm{Mg}=$ magnesium.

*, **Significant at $P<0.05$ or 0.01 , respectively.

${ }^{\mathrm{z}} \mathrm{Ca}$ and $\mathrm{Mg}$ inputs: supplemental $\mathrm{Ca}\left(96 \mathrm{~kg} \cdot \mathrm{ha}^{-1}\right)+$ basal $\mathrm{Mg}\left(56 \mathrm{~kg} \cdot \mathrm{ha}^{-1}\right)$ for Ca; supplemental Ca $\left(73.5 \mathrm{~kg} \cdot \mathrm{ha}^{-1}\right)+$ supplemental Mg $\left(78.5 \mathrm{~kg} \cdot \mathrm{ha}{ }^{-1}\right)$ for $\mathrm{Ca}+\mathrm{Mg}$; basal $\mathrm{Ca}\left(51 \mathrm{~kg} \cdot \mathrm{ha}^{-1}\right)+$ supplemental $\mathrm{Mg}\left(101 \mathrm{~kg} \cdot \mathrm{ha}^{-1}\right)$ for $\mathrm{Mg}$; basal $\mathrm{Ca}\left(51 \mathrm{~kg} \cdot \mathrm{ha}^{-1}\right)$, and basal $\mathrm{Mg}\left(56 \mathrm{~kg} \cdot \mathrm{ha}{ }^{-1}\right)$ for grower standard.

Supplemental Table 2. Interactions for canopy volume and trunk cross-sectional area (TCSA) in Huanglongbing-affected 'Valencia' citrus trees in Nov. 2018 and Sept. 2019, as affected by nitrogen $(\mathrm{N})$ rates and secondary macronutrients.

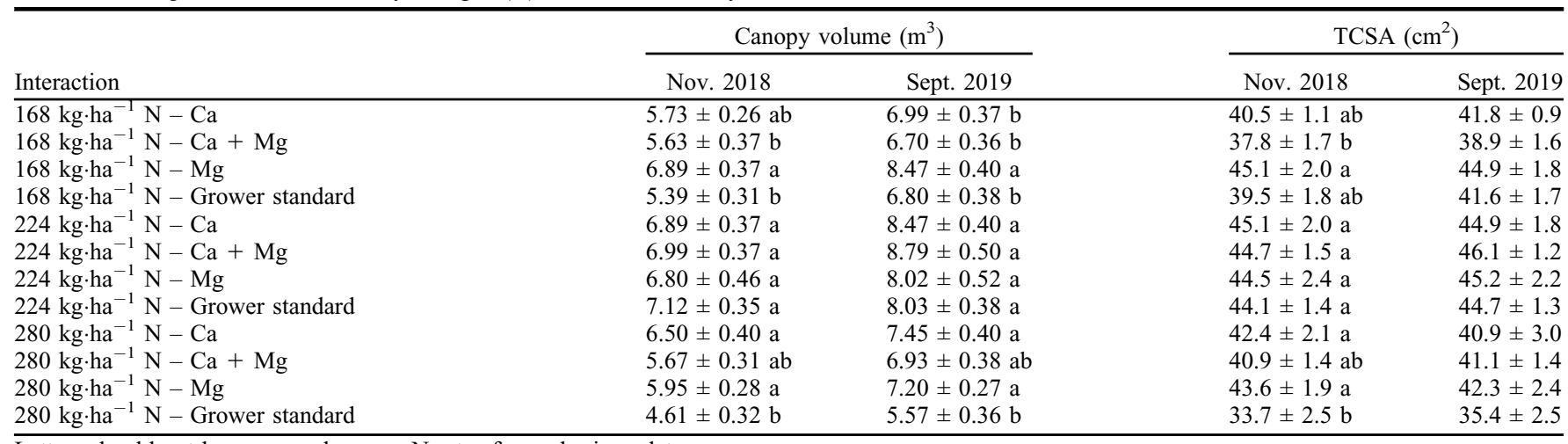

Letters should not be compared among $\mathrm{N}$ rates for each given date.

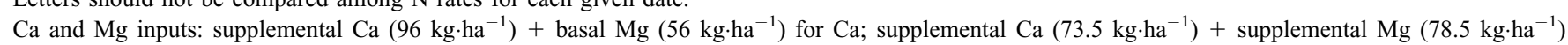
for $\mathrm{Ca}+\mathrm{Mg}$; basal $\mathrm{Ca}\left(51 \mathrm{~kg} \cdot \mathrm{ha}^{-1}\right)+$ supplemental $\mathrm{Mg}\left(101 \mathrm{~kg} \cdot \mathrm{ha}^{-1}\right)$ for $\mathrm{Mg}$; basal Ca $\left(51 \mathrm{~kg} \cdot \mathrm{ha}^{-1}\right)$, and basal $\mathrm{Mg}\left(56 \mathrm{~kg} \cdot \mathrm{ha}{ }^{-1}\right)$ for grower standard. 